\title{
Multilevel Analysis: The Contextual Effect Village on The Risk Hypertension in Magelang, Central Java
}

\author{
Wawan Diyantana1), Dono Indarto'), Bhisma Murti1) \\ 1)Masters Program in Public Health, Universitas Sebelas Maret \\ ${ }^{2)}$ Faculty of Medicine, Universitas Sebelas Maret
}

Background: Hypertension affects one billion people worldwide. Death due to hypertension in the world is estimated at 9.4 million people every year. Factors related to lifestyle can increase the risk of hypertension. In addition, demographic and topographic factors of residence also affect the risk of hypertension. This study aimed to analyze the contextual effect of the village on the risk of hypertension.

Subjects and Method: This study was an observational analytic research study with a cross-sectional approach. This study was conducted in July 2020. A sample of 200 patients who treated at the health center was selected by purposive sampling. The dependent variable was hypertension. The independent variables were obesity, smoking habit, salt consumption, genetic history, age, physical activity, low fiber diet, and stress. Blood pressure was measured with a sphygmomanometer, obesity was measured by body mass index measured by weight scales and stature meters, and other variables with questionnaire. The data analysis used multivariate multiple logistic regression using Stata 13.

Results: The risk of hypertension increased with obesity $\left(\mathrm{BMI} \geq 25 \mathrm{kgBW} / \mathrm{m}^{2}\right)(\mathrm{OR}=5.33 ; 95 \% \mathrm{CI}=$ 1.81 to $15.74 ; \mathrm{p}=0.002)$, smoking habit $(\mathrm{OR}=$
6.28; $95 \% \mathrm{CI}=2.05$ to $19.30 ; \mathrm{p}=0.001$ ), excessive salt consumption $(\mathrm{OR}=2.84 ; 95 \% \mathrm{CI}=0.99$ to $8.11 ; \mathrm{p}=0.051)$, genetic history $(\mathrm{OR}=3.95 ; 95 \%$ $\mathrm{CI}=1.37$ to $11.44 ; \mathrm{p}=0.011)$, age $\geq 45$ years $(\mathrm{OR}=$ $17.71 ; 95 \% \mathrm{CI}=5.81$ to $53.99 ; \mathrm{p}<0.001$ ), lack of physical activity $(\mathrm{OR}=3.49 ; 95 \% \mathrm{CI}=1.19$ to $10.17 ; \mathrm{p}=0.022)$, low fiber $\operatorname{diet}(\mathrm{OR}=12.42 ; 95 \%$ $\mathrm{CI}=1.87$ to $82.49 ; \mathrm{p}=0.009)$, and stress $(\mathrm{OR}=$ $7.59 ; 95 \% \mathrm{CI}=2.22$ to $25.89 ; \mathrm{p}=0.001)$. Village had contextual effect on the risk of hypertension with $\mathrm{ICC}=21.65 \%$.

Conclusion: The risk of hypertension increases with obesity, smoking habit, excessive salt consumption, genetic history, age $\geq 45$ years, lack of physical activity, low fiber diet and stress. Village has contextual effect on the risk of hypertension.

Keywords: contextual effect, village, hypertension

\section{Correspondence:}

Wawan Diyantana. Masters Program in Public Health, Universitas Sebelas Maret. Jl. Ir. Sutami 36A, Surakarta 57126, Central Java. Email: wawandiyantana@gmail.com. Mobile: +6281328710205 .

\section{Cite this as:}

Diyantana W, Indarto D, Murti B (2020). Multilevel Analysis: The Contextual Effect Village on the Risk Hypertension in Magelang, Central Java. J Epidemiol Public Health. 05(03): 270-280. https://doi.org/10.26911/jepublichealth.2020.05.03.02.

c) (i) (2) Journal of Epidemiology and Public Health is licensed under a Creative Commons (c) ${ }_{\mathrm{EY} \text { NC SA }}$ Attribution-Non Commercial-Share Alike 4.0 International License.

\section{BACKGROUND}

The major risk factor for cardiovascular disease is hypertension. Hypertension affects one billion people worldwide and increases the risk of heart attack and stroke. Due to hypertension in the world, deaths are estima- ted at 9.4 million people each year (WHO, 2015).

Hypertension in Magelang in 2018 ranks first for non-communicable diseases in both inpatient and outpatient visits. The prevalence of hypertension in Magelang in 2018 in the adult population was $12.4 \%$, and 
this figure is greater than the prevalence of hypertension in Indonesia in 2018, which was $8.4 \%$ (Magelang District Health Office 2019).

Blood pressure tends to increase with age, so everyone is at risk for hypertension. Lifestyle-related factors can increase the risk of hypertension. These behaviors include consuming too much salt (sodium), not consuming enough potassium (from fruits and vegetables), being overweight, not getting enough exercise, drinking alcohol, and smoking. Hypertension can also be caused by heredity because people can inherit genes that make them more at risk for hypertension (Sudaryanto et al., 2019).

Factors that increase the prevalence of hypertension in adults in Lucknow, India are rapid urbanization, changes in lifestyle, changes in diet, including the use of fast food and salt intake (Khanam et al., 2019)

A study from Istyanto et al. (2019) showed that hypertension in patients at Dr. Moewardi hospital is directly and positively affected by anxiety, stress, poor sleep quality, body mass index (BMI), consumption of coffee and soft drinks. Stress levels have a direct effect on blood pressure. They can also affect sleep quality and body mass index. There was a positive correlation between stress and poor sleep quality. Poor sleep quality increases with stress. There is a positive correlation between stress and body mass index. The body mass index increases with stress.

Hypertension is also affected by demographic and topographic factors where a person lives. Living in urban areas increases the risk of hypertension by 1.33 times compared to rural Indians (Bhansali et al., 2015)

Based on this, the researcher was interested in conducting a study on "Biological and psychological factors as well as the village contextual effect on the risk of hypertension in Magelang Regency."
SUBJECTS AND METHOD

\section{Study Design}

This was a cross-sectional study conducted at Magelang District Health Center, Central Java, Indonesia, in July 2020.

\section{Population dan Sample}

The source population was the population aged 18 - 69 years in the Magelang area. The study sample was 200 people, selected by purposive sampling technique. The study subjects were patients who came for treatment at the health centers with exclusion criteria: being pregnant, using hormonal contraceptives, taking anti-hypertensive drugs, people with diabetes mellitus, people with kidney disease, and consuming alcohol.

\section{Study Variables}

The dependent variable of the study was hypertension. The study's independent variables were obesity, smoking habit, salt consumption, genetic history, age, physical activity, low fiber diet, and stress.

\section{Operational Definition of Variables} Hypertension was the measurement of TDS $\geq 140 \mathrm{mmHg}$ and TDD $\geq 90 \mathrm{mmHg}$. A continuous data scale for analysis purposes was then converted into a dichotomy.

Obesity was the percentage of fat abnormalities expressed in Body Mass Index (BMI) $\geq 25 \mathrm{~kg} / \mathrm{m} 2$. A continuous data scale for analysis purposes was then converted into a dichotomy.

Smoking habit was the behavior of burning tobacco in a roll of paper in the shape of a stick, smoked by mouth and done every day. The data scale was categorical.

Excess salt consumption was a high-sodium diet of more than 2,ooomg or the equivalent of 1 teaspoon (tsp) of salt/person/day, which was characterized by a Preference for foods that tend to be saltier. The data scale was categorical.

Genetic history was a family history of the same child, namely father, mother, grand- 
father, grandmother who has hypertension. The data scale was categorical.

Age was the life span measured from birth to the time of data collection. A continuous data scale for analysis purposes was then converted into a dichotomy.

Lack of physical activity was any movement of the body produced by skeletal muscles and requires energy expenditure as measured by a short-form IPAQ questionnaire. The results were low. The data scale was categorical.

A low-fiber diet is consuming less than five servings of fruits and vegetables per day. The data scale was categorical.

Stress was a condition that was an internal thing, which could be caused by physical demands (body), or the environment, and social situations, which were potentially damaging and uncontrollable. It was measured by the DASS questionnaire with a value $>18$. The scale of continuous data for analysis purposes was converted into a dichotomy.

Village was the geographical and demographic conditions in the administrative area under the sub-district.

\section{Study Instruments}

The study instrument used for data collection was a questionnaire that had been tested for validity and reliability. Digital weighing scale with an accuracy of $0.1 \mathrm{~kg}$, a stature meter with an accuracy of $0.1 \mathrm{~cm}$. Sphygnomanometer and stethoscope were used to measure blood pressure.

\section{Data Analysis}

Univariate analysis was used to determine the distribution of frequencies and percentages of the characteristics of study subjects. Bivariate analysis was carried out between the dependent and independent variables to determine the correlation between the two variables. This bivariate analysis used the chi-square test with a significance level of $p$ $<0.05$ and an odds ratio calculation with a 95\% confidence level. Multivariate analysis used logistic regression analysis with a multilevel approach to determine the village contextual effect on hypertension risk.

\section{Research Ethic}

Ethical clearance in this study was published by the Health Research Ethics Commission of Dr. Moewardi, Surakarta, with number 318/II/HREC/2O2O on March 02, 2020.

\section{RESULTS}

\section{A. Sample Characteristics}

Characteristics of study subjects for continuous data are shown in Table 1 . The characteristics of the categorical data study subjects are shown in Table 2.

\section{Table 1. Characteristics of study subjects (continuous data)}

\begin{tabular}{lccccc}
\hline Characteristics & N & Mean & SD & Min. & Max. \\
\hline Age (year) & 200 & 36.89 & 13.81 & 18 & 69 \\
Systolic blood pressure (mmHg) & 200 & 114.08 & 15.88 & 85 & 170 \\
Diastolic blood pressure (mmHg) & 200 & 76.94 & 9.76 & 60 & 100 \\
Body mass index (kgBB / m2TB) & 200 & 23.27 & 4.29 & 15.20 & 38.40 \\
\hline
\end{tabular}

Table 1 shows that the number of study subjects was 200 people; the average age was 36.89 years. The youngest was 18 years old and the oldest was 69 years old. The mean systolic blood pressure of the study subjects was $114.08 \mathrm{mmHg}$. The lowest systolic blood pressure was $85 \mathrm{mmHg}$ and the highest was
$170 \mathrm{mmHg}$. The mean diastolic blood pressure of the study subjects was 76.94 $\mathrm{mmHg}$. The lowest systolic blood pressure was $60 \mathrm{mmHg}$, and the highest was 100 mmHg. Body mass index (BMI) averaged $23.27 \mathrm{~kg} / \mathrm{m} 2$. The lowest BMI was 15.20 $\mathrm{kg} / \mathrm{m} 2$, and the highest was $38.40 \mathrm{kgBW} / \mathrm{m}^{2}$. 
Diyantana et al./ The Contextual Effect Village on The Risk Hypertension

Table 2. Characteristics of study subjects (categorical data)

\begin{tabular}{lrc}
\hline \multicolumn{1}{c}{ Variable } & N & \% \\
\hline Hypertension & & 78.50 \\
No & 157 & 21.50 \\
Yes & 43 & 69.50 \\
Obesity & 139 & 30.50 \\
Not obese $\left(\mathrm{BMI}<25\left(\mathrm{~kg} / \mathrm{m}^{2}\right)\right.$ & 61 & 81.00 \\
Obesity (BMI $\geq 25\left(\mathrm{~kg} / \mathrm{m}^{2}\right)$ & & 19.00 \\
Smoking habit & 162 & 56.50 \\
Did not smoke & 38 & 43.50 \\
Smoke & & \\
Salt Consumption & 113 & 75.50 \\
Not excessive & 87 & 24.50 \\
Excessive & & 68.50 \\
Genetic history of hypertension & 151 & 31.50 \\
No & 49 & 70.50 \\
Yes & & 29.50 \\
Age & 137 & \\
Age<45 years & 63 & 17.50 \\
Age $\geq 45$ years & & 82.50 \\
Physical activity & 141 & 88.00 \\
Enough physical activity & 59 & 12.00 \\
Fack of physical activity & & \\
Enough fiber diet & 35 & \\
Low fiber diet & 165 & \\
Stress & & \\
No & 24 & \\
Yes & & \\
\hline
\end{tabular}

Table 2 shows the prevalence of hypertension by $21.5 \%$. The prevalence of risk of hypertension and obesity was 30.50\%, smoking $19.00 \%$, excess salt consumption $43.50 \%$, genetic history $24.50 \%$, age $\geq 45$ years $31.50 \%$, lack of physical activity $29.50 \%, 82.50 \%$ low fiber diet and stress $12.00 \%$.

\section{$B$. The result of bivariate analysis}

Bivariate analysis was used to see the independent variable's effect on the dependent variable using the chi-square test. The bivariate analysis of the results of this study can be seen in Table 3 .

\section{The result of multivariate analysis}

Multiple logistic regression analysis with multivariate approaches explained the effect of more than one independent variable (obesity, smoking habit, salt consumption, genetic history, age, physical activity, fiber diet, and stress) on the dependent variable (hypertension). The results of multilevel multiple logistic regression analysis can be seen in Table 4.

The results of the multivariate analysis showed that obesity affected the risk of hypertension. People who had a Body Mass Index $(\mathrm{BMI}) \geq 25$ had a risk of hypertension 5.33 times than people who had a $\mathrm{BMI}<25$ (OR= 5.33, 95\% CI $=1.81-15 \cdot 73, \mathrm{p}=0.002$ ).

Smoking habits affected the risk of hypertension. People who had a smoking habit had a risk of 6.28 times than non-smokers $(\mathrm{OR}=6.28,95 \% \mathrm{CI}=2.05-19.30, \mathrm{p}=0.001)$.

There was an effect of salt consumption on the risk of hypertension. People who have an eating habit of eating salty food had a risk for hypertension by 2.84 times than people 
Diyantana et al./ The Contextual Effect Village on The Risk Hypertension

who have no eating habits of eating salty food $(\mathrm{OR}=2.84,95 \% \mathrm{CI}=0.99-8.11, \mathrm{p}=0.051)$.

Genetic history of hypertension increased risk of hypertension. People who had a family history of hypertension had a risk of hypertension 3.95 times than people without a family history of hypertension $(\mathrm{OR}=3.95,95 \% \mathrm{CI}=1.37$ to $11.44, \mathrm{p}<0.012)$.

Table 3. The results of the bivariate analysis of hypertension risk factors in Magelang

\begin{tabular}{|c|c|c|c|c|c|c|c|c|c|}
\hline \multirow{3}{*}{ Independent Variable } & \multicolumn{4}{|c|}{ Hypertension } & \multirow{2}{*}{\multicolumn{2}{|c|}{ Total }} & \multirow{3}{*}{ OR } & \multirow{3}{*}{$95 \% \mathrm{CI}$} & \multirow{3}{*}{$\mathbf{p}$} \\
\hline & \multicolumn{2}{|c|}{ No } & \multicolumn{2}{|c|}{ Yes } & & & & & \\
\hline & $\mathbf{n}$ & $\%$ & $\mathbf{n}$ & $\%$ & $\mathbf{N}$ & $\%$ & & & \\
\hline \multicolumn{10}{|l|}{ Obesity } \\
\hline $\mathrm{BMI}<25\left(\mathrm{~kg} / \mathrm{m}^{2}\right)$ & 119 & 85.6 & 20 & 14.4 & 139 & 100 & \multirow[b]{2}{*}{3.60} & \multirow[b]{2}{*}{$1.24-7.27$} & \multirow{2}{*}{$<0.001$} \\
\hline $\mathrm{BMI} \geq 25\left(\mathrm{~kg} / \mathrm{m}^{2}\right)$ & 38 & 62.3 & 23 & 37.7 & 61 & 100 & & & \\
\hline \multicolumn{10}{|l|}{ Smoking habit } \\
\hline No & 133 & 82.1 & 29 & 17.9 & 162 & 100 & \multirow{2}{*}{2.68} & \multirow{2}{*}{$1.24-5.79$} & \multirow{2}{*}{0.012} \\
\hline Yes & 24 & 63.2 & 14 & 36.8 & 38 & 100 & & & \\
\hline \multicolumn{10}{|l|}{ Salt Consumption } \\
\hline Not excessive & 96 & 84.9 & 17 & 15.1 & 113 & 100 & \multirow{2}{*}{2.41} & \multirow{2}{*}{$1.21-4.80$} & \multirow{2}{*}{0.013} \\
\hline Excessive & 61 & 70.1 & 26 & 29.9 & 87 & 100 & & & \\
\hline \multicolumn{10}{|l|}{ Genetic history } \\
\hline No & 128 & 84.8 & 23 & 15.2 & 151 & 100 & \multirow{2}{*}{3.84} & \multirow{2}{*}{$1.86-7.90$} & \multirow{2}{*}{$<0.001$} \\
\hline Yes & 29 & 59.2 & 20 & 40.8 & 49 & 100 & & & \\
\hline \multicolumn{10}{|l|}{ Age } \\
\hline$<45$ years & 124 & 90.5 & 13 & 9.5 & 137 & 100 & \multirow{2}{*}{8.67} & \multirow{2}{*}{$4.07-18.46$} & \multirow{2}{*}{$<0.001$} \\
\hline $\begin{array}{l}\geq 45 \text { years } \\
\text { Physical Activity }\end{array}$ & 33 & 52.4 & 30 & 47.6 & 63 & 100 & & & \\
\hline Enough & 117 & 83.0 & 24 & 17.0 & \multicolumn{5}{|c|}{ Physical Activity } \\
\hline Lack & 40 & 67.8 & 19 & 32.2 & 59 & 100 & 2.32 & $1.15-4.67$ & 0.019 \\
\hline Fiber diet & & & & & & & & & \\
\hline Enough & 32 & 91.4 & 3 & 8.6 & 35 & 32 & 241 & $090-1175$ & 0502 \\
\hline Low & 125 & 75.8 & 40 & 24.2 & 165 & 125 & 3.41 & $0.99-11.75$ & $0.05^{2}$ \\
\hline Stress & & & & & & & & & \\
\hline No & 148 & 84.1 & 28 & $15 \cdot 9$ & 176 & 100 & 111 & $105-117$ & $<0001$ \\
\hline Yes & 9 & 37.5 & 15 & 62.5 & 24 & 100 & 1.11 & $1.05-1.17$ & $<0.001$ \\
\hline
\end{tabular}

Table 4. Multilevel multiple logistic regression analysis on the effect of biological, psychological, and contextual village factors on the risk of hypertension

\begin{tabular}{|c|c|c|c|c|}
\hline \multirow{2}{*}{ Independent Variable } & \multirow{2}{*}{ OR } & \multicolumn{2}{|c|}{$95 \% \mathrm{CI}$} & \multirow[b]{2}{*}{$\mathbf{p}$} \\
\hline & & Lower limit & Upper limit & \\
\hline \multicolumn{5}{|l|}{ Fixed Effect } \\
\hline Obesity & $5 \cdot 33$ & 1.81 & $15 \cdot 73$ & 0.002 \\
\hline Smoking habit & 6.28 & 2.05 & 19.30 & 0.001 \\
\hline Salt consumption & 2.84 & 0.99 & 8.11 & 0.051 \\
\hline Genetic history & 3.95 & 1.37 & 11.44 & 0.011 \\
\hline Age & 17.71 & 5.81 & 53.99 & $<0.001$ \\
\hline Physical activity & 3.49 & 1.19 & 10.17 & 0.022 \\
\hline Fiber diet & 12.43 & 1.87 & 82.49 & 0.009 \\
\hline Stress & 7.59 & 2.22 & 25.89 & 0.001 \\
\hline \multicolumn{5}{|l|}{ Random Effect } \\
\hline Var (Constanta) & 0.909 & & & \\
\hline $\mathrm{N}$ observation $=200$ & & & & \\
\hline $\mathrm{N}$ group $=25$ & & & & \\
\hline Log Likelihood= -54.761646 & & & & \\
\hline $\mathrm{p}<0.001$ & & & & \\
\hline Intraclass Correlation $(\mathrm{ICC})=21.65 \%$ & & & & \\
\hline
\end{tabular}




\section{DISCUSSION}

1. The effect of obesity on hypertension

Obesity statistically affects hypertension. A body mass index measures this study's obesity category (BMI) greater than or equal to 25 $\mathrm{m} 2 / \mathrm{kg}$.

This study's results are in line with a study conducted by Amanda et al. (2018), which shows that respondents with obesity have a higher risk of developing hypertension than normal respondents in patients at Sidoarjo health center.

A high body mass index increases the risk of hypertension in Chinese children. Obesity significantly increases hypertension in Chinese children after controlling for age, race, and type of insurance (Xu et al., 2018).

As the body mass increases, the blood volume needed to supply oxygen and food to body tissues increases. As a result, the artery walls will get greater pressure, which causes an increase in blood pressure. In addition, being overweight also increases heart rate (Arifin et al., 2016)

The condition of obesity is associated with increased intravascular volume and cardiac output. Heart pump power and circulating blood volume in obesity will be higher than normal body weight. Weight loss is the element that plays a role in the prevention and treatment of hypertension (Rohkuswara and Syarif, 2017).

\section{The effect of smoking habit on hypertension}

Smoking habit statistically affects hypertension. A study conducted by Susi (2019) showed that smoking habits have a risk of developing hypertension 2,496 times than people with no smoking habit in men aged> 18 years in Bekasi.

The meta-analysis results on cigarette consumption and hypertension in the police and military circles show that cigarette consumption is a risk factor for hypertension.
Cigarette consumption can increase the risk by 1.45 times compared to not consuming cigarettes (Pardosi et al., 2020).

Smoking can increase blood viscosity, stimulate the adrenergic nervous system, and contribute to microvascular and macrovascular diseases. Smoking habits are still considered a major risk factor for hypertension worldwide (Wu et al., 2018).

\section{The effect of salt consumption on hypertension}

Excessive salt consumption affects hypertension. Salt consumption has a significant correlation with the incidence of hypertension in the Bualu Traditional Village community. Respondents who often consume salt are 7.4 times more likely to suffer from hypertension than those who rarely consume salt (Wijaya, 2017).

Excessive salt consumption (more than 5 grams of sodium per day) has resulted in a significant increase in blood pressure. Increased salt consumption can trigger water retention, causing high flow conditions in the arteries (Grillo et al., 2019).

\section{The effect of genetic history on hypertension}

Genetic history has a statistically significant effect on hypertension. This genetic history of hypertension was obtained from parents (father or mother) and grandparents who had hypertension.

This study's results are in line with a study conducted by Kurnianingsih et al. (2017), which showed that adolescents with a family history of hypertension had a higher risk of hypertension by 1.93 units compared to adolescents who did not have a history of hypertension. A study on an elderly Chinese population living in rural Beijing shows a strong association between family history of first-degree relatives and hypertension (Liu et al., 2015).

The effect of family history of hypertension on hypertension increases with kinship 
closeness, where the parental history of hypertension has a higher risk than the history of grandparents. The risk of hypertension increases if you have more than one hypertensive family member (Alhawari et al., 2018).

\section{The effect of age on hypertension}

The age factor significantly affects hypertension. More than or equal to 45 years has a risk of hypertension by 21.44 times than those aged less than 45 years.

A study conducted by Ismail et al. (2016) explained that increasing age is a major risk factor for increasing blood pressure in coastal populations in South India.

The increased risk of hypertension at age $\geq 45$ years occurs due to atherosclerotic changes with age so that the arteries and arterioles become less elastic. Arteries and arterioles that are not elastic cause an increase in blood pressure. The prevalence of hypertension is found to continue to increase with age. The lowest prevalence of hypertension was seen in the 18-25 age group, and in the 56 to the $60-y e a r$ age group, the prevalence of hypertension increased with a statistically significant difference (Laxman, 2018).

As you get older, your blood pressure will also increase. The arterial walls will experience thickening caused by the buildup of collagen substances in the muscle layer, resulting in blood vessels narrowing and becoming stiff after the age of 40 (Amanda and Martini, 2018).

Another condition that supports the incidence of hypertension in old age is that telomeres are known to shorten with age. Telomere shortening is progressive with aging and is associated with cardiovascular disease. Short telomeres increase the risk of hypertension (Zgheib et al., 2018).

\section{The effect of physical activity on hy- pertension}

Physical activity affects the occurrence of hypertension. People with a lack of physical activity have 3.88 times the risk for hypertension than people who have enough physical activity.

These results are in line with a study conducted by Amra et al. (2020), which stated that parents in Aceh Singkil, namely people who lack physical activity, have a risk of hypertension 2.86 times who have enough activity.

Isotonic and regular exercise can reduce peripheral resistance, lower blood pressure in people with hypertension, and train the heart muscle so that it becomes accustomed to when the heart has to do heavier work. Lack of physical activity will increase the likelihood of obesity. Inactive people also tend to have a higher heart rate, so the heart muscle has to work harder with each contraction (Wijaya, 2017).

The mechanism by which physical exercise can affect blood pressure is the regulation of endothelial function. Vascular homeostasis relies on endothelial activity, which is a fundamental regulator of vasomotor response and vascular resistance. Hypertension is characterized by microvascular refinement caused by impaired angiogenesis. Constant physical exercise has been shown to induce blood vessels and increase blood flow (Gambardella et al., 2020).

\section{The effect of fiber diet on hyper- tension}

A low-fiber diet increases the risk of hypertension. People who eat fruits and or vegetables $<5$ servings per day have a risk for hypertension by 10.27 times than people whoeat fruits and or vegetables $\geq$ five servings per day.

A prospective cohort study of women and men in the United States suggests the long-term intake of total fruit is associated with a reduced risk of hypertension. Raisins, grapes, apples, pears, blueberries, and avocados, when consumed $\geq 4$ servings/week, can reduce hypertension risk (Borgi et al., 2016). 
A prospective cohort study of adults in Korea found that frequent fruit consumption (4 servings/day) reduced the risk of hypertension $56 \%$ to $67 \%$ lower than fruit consumption $<1$ serving/day. Fruit is rich in many nutrients with anti-oxidant properties, such as flavonoids, anthocyanins, polyphenols, fiber, vitamin $\mathrm{C}$, potassium, and magnesium, associated with lowering blood pressure (Kim et al., 2018).

Vegetables and fruit are a group of foods rich in potassium. High potassium intake can lower blood pressure. Potassium's mechanism in preventing narrowing of blood vessels (atherosclerosis) is by keeping arterial artery walls elastic and optimizing their function, so they are not easily damaged by high blood pressure. Potassium's mechanism is opposite to sodium, which tends to draw fluid from the extracellular part and reduce blood pressure (Leo et al., 2020).

\section{The effect of stress on hypertension}

Stress factor has a statistically significant effect on hypertension. People who experience stress have an increased risk of hypertension by 6.15 times than people who are not stressed.

This study's results are in line with a study conducted by Arifin et al. (2016), which stated that there is a significant correlation between stress levels and the incidence of hypertension in the elderly in Badung, Bali. Stress is an independent risk factor for hypertension in adults. Stress has a chance of hypertension 2.49 times (Bhelkar et al., 2018).

A study in Wisconsin, United States, showed individuals with high hair cortisol were twice as likely to develop hypertension as those with low hair cortisol. Increased systemic cortisol can cause vascular endothelial dysfunction. High cortisol levels inhibit the expression of induced nitric oxide synthase, decrease the availability of endothelial nitric oxide, and increase regional vascular resistance, leading to increased blood pressure and hypertension (Bautista et al., 2019).

Stress can stimulate the kidneys to release the hormone adrenaline. The hormone adrenaline can increase blood viscosity and cause blood pressure to increase. The hormone adrenaline also plays a role in accelerating the heart rate and affects blood vessels' constriction. As a result, the heart will beat stronger to increase blood pressure (Arifin et al., 2016).

\section{The effect of the contextual village on hypertension}

The results of this study obtained an Intra Class Correlation (ICC) value of $17.31 \%$, which means that the context of the village in Magelang affects the risk of hypertension. The variations in the villages in this study include area topography and population density.

Villages that are in the lowlands with high population density have the highest prevalence of hypertension. The highest risk factors in the densely populated lowland village group are genetic history, age $\geq 45$ years, excess salt consumption, obesity, lack of physical activity, and stress.

Lowland villages with high population density have a typology similar to urban areas. A study conducted by Khanam et al. (2019) on differences in the prevalence and determinants of rural-urban hypertension in adults in Bangladesh stated that the prevalence of hypertension in urban areas is $32.6 \%$ and in rural areas $23.6 \%$. Several risk factors, such as obesity, diabetes, and wealth status, are more concentrated in urban areas so that urban residents have a higher risk of hypertension.

A study conducted by Daştan et al. (2017) concerning urban and rural differences in risk factors for hypertension in Turkey found that the factors that contribute to the risk of hypertension show some variation 
based on urban and rural areas. This study found that the factors associated with hypertension in urban areas were marital status, type of work, and lifestyle, including diet. Psychological factors have also been found to be associated with hypertension.

The conclusion obtained from the study is that there is a significant effect between obesity, smoking habit, excessive salt consumption, the genetic history of hypertension, age $\geq 45$ years, lack of physical activity, low fiber diet, and stress on the risk of hypertension. Variation in the village shows a contextual effect on the risk of hypertension.

\section{AUTHOR CONTRIBUTION}

Wawan Diyantana as the main researcher and research implementer, collected study data, prepared articles of the study, and processed data. Dono Indarto played a role in the preparation of the background and discussion of the study. Bhisma Murti played a role in formulating a study framework of thinking and analyzing research data.

\section{CONFLICT OF INTEREST}

There is no conflict of interest in this study.

\section{FUNDING AND SPONSORSHIP}

This study's source of funding used the Budget from the Health Human Resources Development and Empowerment Agency, Indonesian Ministry of Health, in 2020.

\section{ACKNOWLEDGEMENT}

The researchers would like to express their gratitude to the Head of the Magelang District Health Office. Head of UPT health center technical implementation unit at Magelang for permitting to conduct this study and outpatients who have been willing to study subjects.

\section{REFERENCE}

Alhawari $\mathrm{HH}$, Al-Shelleh S, Alhawari HH, Al-Saudi A, Aljbour AD, Al-Faris L,
Al-Ryalat SA (2018). Blood pressure and its association with gender, body mass index, smoking, and family history among university students. Int $\mathrm{J}$ Hypertens. 1-5. doi:10.1155/2018/4186496.

Agnes A, Leo R (2020). Hubungan konsumsi laru, garam, sayur, dan buah terhadap risiko hipertensi pria dewasa Kupang. JIGK, 1(02): 1-9.

Amanda D, Martini S (2018). The relationship between demographical characteristic and central obesity with hypertension. JBE. 6(1): 43. doi:10.20473/jbe.v6i12018.43-50.

Amra RN, Aguslina Siregar F, Mutiara E (2020). Physical activity, obesity, family history, and their associations with hypertension among the elderly in Aceh Singkil, Aceh. J Epidemiol Public Health. 5(1): 45-51. https://doi.org/10.26911/jepublichealth.2020 .05.01.05.

Arifin MHBM, Weta IW, Ratnawati NLKA (2016). Faktor-faktor yang berhubungan dengan kejadian hipertensi pada kelompok lanjut usia di wilayah kerja UPT Puskesmas Petang I Kabupaten Badung Tahun 2016. E-Jurnal Medika, 5(7): 1-22.

Bautista LE, Bajwa PK, Shafer MM, Malecki KMC, McWilliams CA, Palloni A (2019). The relationship between chronic stress, hair cortisol and hypertension. Int $\mathrm{J}$ Hypertens. 2: 100012. doi: 10.1016/j.ijchy.2019.100012.

Bhansali A, et al. (2015). Prevalence of and risk factors for hypertension in urban and rural India: The ICMR-INDIAB study. J Hum Hyperten. 29(3): 204209. doi: 10.1038/jhh.2014.57.

Bhelkar S, Deshpande S, Mankar S, Hiwarkar P (2018). Association between stress and hypertension among adults 
Diyantana et al./ The Contextual Effect Village on The Risk Hypertension

more than 30 years: A case-control study. Natl J Community Med; 9(6): 430-433.

Borgi L, Muraki I, Satija A, Willett WC, Rimm EB, Forman JP (2016). Fruit and Vegetable Consumption and the Incidence of Hypertension in Three Prospective Cohort Studies. Hyper tension, 67(2), 288-293. doi: 10.1161/hypertensionaha.115.06497.

Daştan İ, Erem A, Çetinkaya V (2017). Urban and rural differences in hypertension risk factors in Turkey. Anatol. J. Cardiol, 18(1), 39-47. doi: 10.14744/AnatolJCardiol.2017.7452.

Dinkes Kab Magelang (2019) Profil Kesehatan Kabupaten Magelang. Magelang.

Gambardella J, Morelli MB, Wang X, Santulli G. (2020). Pathophysiological mechanisms underlying the beneficial effects of physical activity in hypertension. J Clin Hypertens, 22(2), 291295. doi:10.1111/jch.13804.

Grillo A, Salvi L, Coruzzi P, Salvi P, Parati $G$ (2019). Sodium intake and hypertension. Nutrients, 11(9), 1-16. doi:10.3390/nu11091970.

Ismail IM, Kulkarni AG, Meundi AD, Amruth $M$ (2016). A community-based comparative study of prevalence and risk factors of hypertension among urban and rural populations in a coastal town of South India. Sifa Medical Journal, 3(2): 41. doi: 10.4103/2148-7731.182001.

Istyanto F, Mudigdo A, Rahardjo SS (2019).

Path Analysis on the Biopsychosocial Factors Associated with Hypertension. J Epidemiol Public Health. 4(2) 70-80. doi: 10.26911/jepublichealth.2019.04.02.02.

Khanam R, Ahmed S, Rahman S, Al Kibria GM, Syed JRR, Khan AM, Moin SMI, Ram M, Gibson DG, Pariyo G, Baqui $\mathrm{AH}$ (2019). Prevalence and factors associated with hypertension among adults in rural Sylhet district of Bangladesh: a cross-sectional study. BMJ Open 9:e026722. doi: 10.1136/bmjopen-2018-026722.

Kim J, Kim J (2018). Association between fruit and vegetable consumption and risk of hypertension in middle-aged and older Korean adults. J Acad Nutr Diet. 118(8): 1438-1449.e5. doi:10.1016/j.jand.2017.08.122.

Kurnianingsih M, Dewi YLR, Pamungkasari EP (2019). Risk factors of hypertension in high school students: Multilevel evidence of the contextual effect of school. J Epidemiol Public Health. 4(4): 259-269. doi: 10.26911/jepublichealth.2019.04.04.01.

Laxman S (2018). A Study of hypertension and its risk factors among rural population in the field practice area of Mahatma Gandhi Medical College and Hospital, Jaipur. J med sci clin res. 6(5). doi:10.18535/jmscr/v6i5.11.

Pardosi F, Rahardjo SS, Dewi YLR (2020). Overweight, alcohol, and tobacco consumption are associated with hypertension among police and military personnel: A meta-analysis. J Epidemiol Public Health. 5(1), 88-96. doi: 10.26911/jepublichealth.2020.05.01.09.

Rohkuswara TD, Syarif S (2017). Hubungan obesitas dengan kejadian hipertensi derajat 1 di pos pembinaan terpadu penyakit tidak menular (Posbindu PTM) Kantor Kesehatan Pelabuhan Bandung Tahun 2016. Jurnal Epidemiologi Kesehatan Indonesia, 1(2). doi:10.7454/epidkes.v1i2.1805.

Sudaryanto S, Rahardjo SS, Indarto D (2019). Risk factors of hypertension among women in Sragen, Central Java. J Epidemiol Public Health. 4(2): 127-137. doi: 10.26911/jepubliche- 
Diyantana et al./ The Contextual Effect Village on The Risk Hypertension

alth.2019.04.02.08.

Susi DDA (2019). Hubungan antara kebiasaan merokok terhadap kejadian hipertensi essensial pada laki-laki usia di atas 18 tahun di RW o6, Kelurahan Medan Satria, Kecamatan Medan Satria, Kota Bekasi. Tarumanagara Medical Journal, 1(2): 434-441.

WHO (2015). Q\&As on hypertension. Retrieved from https://www.who.int/news-room/q-a-detail/q-as-on-hypertension (Accessed: 2 January 2020).

Wijaya IPA (2017). Factors affecting blood pressure increase in the event of hypertension indigenous community in Bualu. Caring, 1(04): 13-24.

Wu J, Li T, Song X, Sun W, Zhang Y, Liu Y, Li L, et al. (2018). Prevalence and distribution of hypertension and related risk factors in Jilin Province, China 2015: A cross-sectional study. BMJ

Open, 8(3): 1-10. doi: 10.1136/bmjopen-2017-020126.

Xu RY, Zhou YQ, Zhang XM, Wan YP, Gao $X$ (2018). Body mass index, waist circumference, body fat mass, and risk of developing hypertension in normalweight children and adolescents. Nutr Metab Cardiovasc Dis 28(10) 10611066. doi: 10.1016/j.numecd.2018.05.015 .

Zgheib NK, Sleiman F, Nasreddine L, Nasrallah M, Nakhoul N, Isma'eel, $\mathrm{H}$, Tamim H (2018). Short telomere length is associated with aging, central obesity, poor sleep and hypertension in lebanese individuals. Aging Dis. 9(1): 77-89. doi: 10.14336/AD.2017.0310. 